University of Wollongong

Research Online

Faculty of Business - Papers (Archive)

Faculty of Business and Law

2013

Real stories about real women: communicating role models for female tourism students

Ulrike Gretzel

University of Wollongong, ugretzel@uow.edu.au

Gillian Bowser

Colorado State University

Follow this and additional works at: https://ro.uow.edu.au/buspapers

Part of the Business Commons

Research Online is the open access institutional repository for the University of Wollongong. For further information contact the UOW Library: research-pubs@uow.edu.au 


\title{
Real stories about real women: communicating role models for female tourism students
}

\begin{abstract}
This article identifies the lack of role models as an important factor that discourages women from taking on leadership roles in tourism communities, government agencies, companies, and academia. Based on discussions of the current literature on role models and the importance of stories, the article presents case studies of initiatives that use social media to collect and share the stories of female role models. The article then discusses opportunities to replicate such initiatives within the tourism education context to provide female students and educators with opportunities to identify with and be encouraged by the real stories of real female tourism leaders.
\end{abstract}

\section{Keywords}

stories, about, women, communicating, real, role, tourism, models, female, students

\section{Disciplines \\ Business}

\section{Publication Details}

Gretzel, U. \& Bowser, G. (2013). Real stories about real women: communicating role models for female tourism students. Journal of Teaching in Travel and Tourism, 13 (2), 170-183. 
Real stories about real women: Communicating role models for female tourism students

Ulrike Gretzel

Institute for Innovation in Business and Social Research

University of Wollongong

Wollongong, Australia

ugretzel@uow.edu.au

Gillian Bowser

Natural Resource Ecology Laboratory

Colorado State University

Fort Collins, Colorado, USA

Gillian.Bowser@colostate.edu

\begin{abstract}
The paper identifies the lack of role models as an important factor that discourages women from taking on leadership roles in tourism communities, government agencies, companies and academia. Based on discussions of the current literature on role models and the importance of stories, it presents case studies of initiatives that use social media to collect and share the stories of female role models. The paper then discusses opportunities to replicate such initiatives within the tourism education context to provide female students and educators with opportunities to identify with and be encouraged by the real stories of real female tourism leaders.
\end{abstract}

Keywords: role model, leadership, gender, storytelling, social media

Running head: Real stories about real women 
"We cannot solve global problems using half of the world's brain power." Monika Devikka

\section{INTRODUCTION}

Understanding tourism requires a gendered perspective as all tourism activities and processes emerge from a gendered society and affect genders in different ways (Apostolopoulos, Sönmez \& Timothy, 2001; Byrne Swain, 1995; Kinnaird \& Hall, 1994). Gender refers to “... a system of culturally constructed identities, expressed in ideologies of masculinity and femininity, interacting with socially structured relationships in divisions of labor and leisure, sexuality, and power between women and men" (Byrne Swain, 1995: 258-259). Gender stereotypes and gender-discriminating practices embedded in society are transferred to and reproduced within tourism education and the tourism industry. This leads to great gender inequalities in tourism employment (Costa, Carvalho, Cacador, \& Breda, 2012). Although gender and tourism have been discussed to some extent in the tourism literature (Sinclair, 1997), policy related to tourism and especially tourism education is still to a large extent gender-blind (Ferguson, 2009). The Tourism Education Futures Initiative (TEFI) 2011 meeting in Philadelphia started discussions on viewing tourism education through a gender lens but no concrete efforts were initiated in response to the gender-related panel discussions. This paper seeks to rekindle the interest in a gender-equal future for tourism and suggests a concrete project as a step towards mobilizing greater gender-awareness in tourism education and supporting leadership development in women. In support of the project idea, it presents case studies of initiatives that aim(ed) at fostering gender equality through role models that portray "real women" instead of models or celebrities and used social media extensively to mobilize interest and participation in the projects.

\section{FEMALE LEADERSHIP IN TOURISM}


The tourism industry seems to be a particularly important sector for women, providing a wide range of income-generation opportunities for women, especially in developing regions (UN Women, 2011). There are also clear leadership opportunities for women in tourism. Women are almost twice as likely to be employers in tourism compared to other sectors, and women account for one in five tourism ministers worldwide, which is more than in any other branch of government (UN Women, 2011). However, like in other sectors, there is a significant horizontal and vertical gender segregation of the labour market in tourism, with certain types of professions (e.g. chambermaids), lower level jobs, and occupations with few career development opportunities being dominated by women (Costa, Carvalho, \& Breda, 2011; EarthSummit2002.org, 2002). Only one in five tourism board CEOs are women and only $23 \%$ of tourism industry associations have a female chair person (UNWTO, 2011). The UNWTO report also stresses that while the proportion of women graduates in all fields of education is increasing, there is still a shortage of women teaching at the tertiary level.

King, McKercher and Waryszak (2003) illustrate that in many Western countries women make up a majority of tourism and hospitality student cohorts but about half of these students never enter the industry and those who do mostly occupy lower level positions. Hjalager (2003) shows that female tourism students are less ambitious than male students, aiming mostly for middle management positions and considering a significantly narrower range of career opportunities. It is also worth noting that none of the female students in the sample considered embarking on an academic career path. Hjalager concludes that perceived career prospects and attitudes toward work life in the tourism industry are highly influenced by traditional gender patterns, with female students being less adventurous and less keen to work in large organizations. Similarly, Costa et al. (2012) report that female tourism students in 
Portugal are less likely to indicate that they would like to take on a leadership position than their male counterparts and also have lower salary expectations.

Only 14 percent of FTSE 100 directorships are held by women and women are also significantly less likely to hold senior management positions in these organizations (Garcea, Linley, Mazurkiewicz, \& Bailey, 2012). Rice (2012a) specifically looks at the lack of women in academic careers and points out that women see academic careers as more all-consuming, solitary and unnecessarily competitive than men and perceive great sacrifice as a prerequisite for success in academia. They are further told that they will have more problems simply because they are women. All these factors discourage them from pursuing respective career options. Pritchard, Morgan, Ateljevic and Harris (2007) report that “...structural gender inequalities remain depressingly intact in the world's higher education academies" (p. 3), indicating that female doctoral graduates are more likely to pursue careers in the more family-friendly private sector and those females who pursue academic careers being less likely to have tenure than their male colleagues. Lack of female leadership is very visible in the tourism academy with only six women listed among the leading tourism scholars (Zhao \& Ritchie, 2007) and only eight out of 70 fellows of the International Academy for the Study of Tourism being women.

Therefore, while tourism programs around the world attract a large number of female students, these female students often lack role models in leadership positions in industry, academia, government and communities. This is especially true for women of underrepresented groups as they have an even smaller likelihood of being represented in leadership positions. The United Nations Environment and Development UK Committee stresses that sharing of experiences and networking among women are critical in supporting women in 
their pursuit of leadership roles in tourism (Earthsummit2002.org, 2002). This paper reflects on the importance of role models and opportunities to take advantage of new media to collect and widely communicate stories about female leaders in tourism in order to inspire more women to consider leadership roles in the tourism industry, tourism-related government bodies, NGOs, and academia.

\section{LEADERSHIP FOR TRANSFORMATION}

Management focuses on keeping current systems functioning while leadership is essentially about producing change. Leadership for transformation as a concept refers to leadership that brings about fundamental changes to systems. It is therefore a broader concept than traditional transformational leadership, which concentrates on unleashing potential and instigating changes in followers (Bass, 1985). Ackoff (1999) explains systemic transformation as follows: "A system is transformed when the type of system it is thought to be is changed" (p.25). Accordingly, leadership for transformation is leadership that can produce and mobilize a vision of a transformed system. Isaksen and Tidd (2006) stress that leadership for transformation requires integration of leadership, management, creativity and innovation and emphasize that it is not exclusive to higher levels in organizational structures but, rather, happens across functions and levels. They also point out that leadership for transformation requires recognition of the full spectrum of talent in the entire employee population. Yet, focusing on female talent and leadership development can be an organizational taboo (Garcea et al., 2012).

\section{Female Leaders as Change Agents}

Female leaders are seen as instrumental for ending gender inequalities in the workplace as gender gaps are wider, the stronger the male representation among organizational managers 
and supervisors (Hultin \& Szulkin, 2003). The explanations for this phenomenon cited in the literature include in-group preference and stereotyping as well as out-group exclusion (Gorman, 2005). Therefore, female leaders are often conceptualized as change agents necessary to break the vicious cycle of male leaders cultivating male-dominated organizational structures and cultures. For such change to happen, it is important that women reach the highest levels of leadership in organizations. However, women generally report lower confidence in regard to their careers (Garcea et al., 2012) and women are selected less often as leaders than is suggested by their past performance due to the general overconfidence of males in their representation (Reuben, Rey-Biel, Sapienza, \& Zingales, 2012). Further, leaders are typically seen as possessing qualities that are stereotypically masculine (e.g. assertiveness, rationality). This creates problems for female leaders who need to fulfil a leader role while at the same time balancing their gender role (Kark, Waismel-Manor, \& Shamir, 2012). However, transformational leadership and leadership for transformation are often associated with feminine values such as caring and compassion, which might actually provide women with an advantage (Eagly \& Carli, 2003).

A recent study by Stainback and Kwon (2012) finds that only women in higher levels of organizational power actually lead to lower levels of sex segregation while a large percentage of women in supervisory positions is associated with higher levels of sex segregation. Ely (1994) suggests that social identity theory is the key to understanding whether female leaders will actually make a difference in the workplace. She finds that women in firms with few senior-level female leaders are less likely to perceive female leaders as role models and find less support in relationships with them because they see them as women who had to give up their identity as women in order to reach these high ranks. The research therefore suggests that being able to be seen as a role model is critical in motivating other women to follow suit 
but that not all female leaders are automatically seen as role models suggesting that it is possible and desirable for women to reach high level leadership positions.

\section{Importance of Role Models}

A role model is a person whose behaviour in a particular role is imitated by others (Merriam Webster Online, 2012). Role models are looked up to and revered and provide concrete examples to follow. Role models positively influence aspirations and self-perceptions by means of social comparison processes (Hoyt \& Simon, 2011). They serve an essential function in socialization processes. Consequently, role models have important impacts on career choices (Wright, Wong, \& Newill, 1997) and are seen as critical in inspiring future leaders (Gibson \& Cordova, 1999). Cheryan et al. (2011: 661) point out that "interacting with one member of a field, even briefly, can shape students' beliefs about their potential for success in that field". Therefore, creating opportunities for exposure to role models is important in shaping the career aspirations of current students, especially when they are female. Women tend to underestimate their potential for success but their expectations can be modified if exposed to role models they can identify with (Rice, 2012b).

Existing research has looked at how characteristics of role models moderate their positive impacts on aspirations. Females can have male role models but the sex of an authority model can matter under some circumstances (Geis, Boston, \& Hoffman, 1985). Lockwood (2006) shows that women are more inspired by female career role models who demonstrate that gender barriers can be overcome. Similarly, Cheryan et al. (2011) reveal through experimental research that the most important criterion for positive influence is whether the role model embodies stereotypes that are seen as congruent with the female gender role. For example, successful female professors are often perceived by female $\mathrm{PhD}$ students as 
displaying masculine characteristics, such as aggression and competiveness, and they are often childless, thus confirming negative stereotypes rather than challenging them (Rice, 2012a). Females who display such stereotypical characteristics are not likely to serve as an inspiration for women who would like to pursue a similar career. In brief, women see themselves as outsiders and are influenced when they perceive that outsiders can make it (Rice, 2012b).

Rios, Stewart and Winter (2010) find that female students benefit greatly from a curriculum that features female exemplars in terms of identification with female leaders and changes in perceptions of career opportunities. Unfortunately, female role models are hard to find in top leadership positions due to negative stereotypes and discrimination against women in the leadership domain (Eagly \& Carli, 2007). Beaman, Duflo, Pande and Topalova (2012) find that quotas can help in that the resulting exposure to female leadership raises aspirations and educational attainment for girls in villages with female council leaders.

However, role models can only inspire and provoke self-enhancement when their success seems achievable (Lockwood \& Kunda, 1997). Hoyt and Simon (2011) suggest that perceiving success to be attainable is particularly important for women who have to perform in a negatively stereotyped leadership domain. Top level female leaders are likely seen as exceptions to the rule (Dasgupta \& Asgari, 2004). A review of research that deals with the relationship between stereotypes, gender and effectiveness of role models is provided by Betz and Sekaquaptewa (2012) and further illustrates its complexity. Research by Hoyt and Simon (2011) demonstrates that the critical characteristic is not how far removed the leadership level is but how able women are to identify with these female role models. As such, same sex role 
models can be more effective but they have to involve "real" women whose accomplishments are seen as replicable.

Importantly, as opposed to mentors and sponsors, direct interaction with a role model is not necessary for impacts (Gibson \& Cordova, 1999). This opens up opportunities as to who could serve as a role model that should be seized. If the number of potential role models is small, sharing their stories across a wide population of female students becomes essential.

\section{THE POWER OF STORIES AS A COMMUNICATION MEDIUM}

Stories represent powerful means of communicating knowledge (Schank \& Abelson, 1995) and they are generally seen as an essential structure for human meaning making (Bruner, 2002). They are perceived as more persuasive than other text genres (Padgett \& Allen, 1997) because the specific structure of stories influences the way in which they are processed. According to Packer and Jordon (2001), stories allow the human mind to "collapse boundaries of space and time, drawing attention to previously undetected connections, creating links between disparate ideas and elements" (p. 174). Some researchers claim that this is the case because the structure of stories resembles the associative way the human mind stores knowledge (Schank \& Abelson, 1995). They are also inherently entertaining (Brewer, 1988), which makes it easier to pay attention to them and fosters recall. Slater and Rouner (2002) further indicate that a student's absorption in a narrative and response to characters in a narrative enhances persuasive effects and reduces counterarguing for contexts in which the content of the story is counterattitudinal, while also limiting the influence of topic involvement. Stories are especially useful in situations of uncertainty and ambiguity (Fleming, 2001). According to Rossiter (2002), stories encourage deep involvement of the learner and this involvement stimulates empathic response. She explains that the details and 
vivid imagery communicated through stories foster both cognitive appreciation and affective response to the experience of another person and are therefore especially useful for situations where identification with a role model is desirable.

The importance and persuasive power of stories has been recognized in various fields, including leadership (Parkin, 2004; Fleming, 2001). Shamir, Dayan-Horesh and Adler (2005) propose that a leader's life story can be an important source of influence and that the meaning(s) it communicates can help enact leadership roles. Neuhauser (1993) stresses the importance of stories as management tools due to their believability based on perceived authenticity and credibility. Storytelling has also been identified as an important means of constructing social bonds (Kraus, 2006), which is a critical issue in building mentoring relationships. Driscoll and McKee (2006) recognize storytelling by leaders as a vital component of authentic transformational leadership.

New technologies such as social media make it increasingly possible to collect rich multimedia stories and distribute them. The Merriam Webster Online Dictionary (2012) defines social media as forms of electronic communication (for instance Web sites for social networking and microblogging) through which users create online communities to share information, ideas, personal messages, and other content (e.g. photos and videos). Web 2.0 as a technological platform but also as a philosophy regarding control over content provides important opportunities for information to be exchanged. Content in the social media space is to a large extent created by consumers for consumers. It is typically based on real experiences by real people, which contributes to the high credibility and perceived authenticity of social media messages. The emergence of social media also created a culture of putting the self constantly on display, revealing intimate details of one's life story. Therefore, social media 
are critical means of social identity construction and portrayal. Importantly, social media encourage social interactions, which means that contents can be jointly created and easily shared, allowing information to quickly spread through social networks. The narrative quality of social media and their resulting persuasive communication potential has been researched in the context of travellers sharing their tourism experiences (Gretzel et al., 2011) but has yet to be explored in the context of tourism education and leadership in tourism.

\section{Case Studies of Stories by Real Women}

The following describes cases in which social media in conjunction with consumer-generated stories were successfully used to expose a wide audience to role models based on "real women"; therefore they can be seen as instrumental to understanding how these different domains can be effectively combined (Stake, 1995). Companies have already taken advantage of the opportunity to elicit authentic consumption stories using social media (see Dove campaign for real beauty: http://www.dove.co.uk/campaign-for-real-beauty.html), thereby creating very persuasive campaigns with powerful message contents. Instead of using highly idealized and photo-brushed models, these stories portray women with whom others can easily identify. They therefore present role models in positions that are seen as not only desirable but also achievable. The Dove campaign was recognized with two Grand Prix Cannes Advertising Awards in 2007. It had as one of its explicit goals encouragement of women to participate in the discussion by casting votes and posting comments on the campaign website. It led to the development of the Dove Self-Esteem Fund with the goal of educating girls and women about a wider definition of beauty (http://www.dove.us/SocialMission/campaign-for-real-beauty.aspx). The website further reveals that in 2010 the Dove Movement for Self-Esteem was founded to provide women with opportunities to mentor the 
next generation. The Movement has resulted in the development of self-esteem building, educational programs and activities, which have until now reached 7 million girls.

The question is if and how social media can be used to elicit stories to inspire women to become female leaders the same way they inspired them to use Dove products. An example of how social media can be used to mobilize leaders among women is "1 Million Women", a not-for-profit organization who uses social media to engage women in climate change actions (http://www.1millionwomen.com.au/). Its goal is to encourage women to actively reduce $\mathrm{CO} 2$ emissions in their own lives and to create a powerful network of women ambassadors for climate change. Like Dove, the campaign uses the faces and stories of real women to inspire others to engage in leadership efforts. Again, social media are employed to capture and share the stories of those women who have dedicated themselves to playing a leadership role in the effort. 1 Million Women has grown into one of the largest non-political women's organizations in Australia. It is one of the largest member-based environmental groups, with nearly 80,000 members, 36,000+ on Facebook and about 9000 women and girls having attended one of its events (http://www.newsmaker.com.au/news/20596). The Australian Prime Minister Julia Gillard backed one of its recent campaigns called Recipe for Change (http://www.1millionwomen.com.au/), which involved encouraging women across Australia to host a get-together of women to discuss ways in which women can save the earth. As a result of the campaign, thousands of Australian women got together to exchange ideas about how to save energy and reduce waste (http://recipeforchange.1millionwomen.com.au/).

Other examples can be extracted from the efforts of the Global Women Scholars Network (GWSN) (for more information see http://globalwomenscholars.wordpress.com/) funded by the United States National Science Foundation to cultivate leadership among women in 
sustainability-related sciences

(http://nsf.gov/awardsearch/showAward.do?AwardNumber=1140182). The GWSN is a network of female scholars and scholars interested in gender issues pertaining to sustainability research, recognizing that climate change affects women in different ways and that a female perspective is needed in solving global sustainability problems. As a research collaborative network it is charged with connecting these scholars on a global scale in order to change the face of climate change and sustainability research. Mentoring is a key aspect of GWSN's activities, recognizing the importance of providing role models and support to female scholars. While the network actively hosts workshops to co-locate scholars in physical space, it quickly realized that inspiration and role modelling is required on a more global scale in order to initiate change. It therefore initiated a project to collect stories of female role models in order to acknowledge them and to make their insights available to women around the world interested in tackling climate change and sustainability problems. The initiative aims at celebrating transformational leaders and potentially encouraging a new generation of female students to pursue leadership roles who would otherwise not have identified with such opportunities.

Starting with a small group of female leaders organized under the umbrella of Climate Wise Women (http://climatewisewomen.org/?page_id=12), the GWSN initiative seeks to create rich and convincing portrayals of the important role women play in guiding climate change efforts in communities, industry, government and academia. One of the Climate Wise Women is Ursula Rakova, who is leading the Carteret Islands evacuation efforts. Her story has been captured through a traditional documentary called "Sun Come Up" as well as told and retold through various YouTube videos and blog entries available online (http://journeytothesinkinglands.wordpress.com/). Additional stories were collected from 
women who were instrumental in driving gender issues forward within the United Nations climate change summits during the Rio+20 climate change summit in 2012. A small selection of stories is available through the GWSN Youtube channel (http://www.youtube.com/globalwomenscholars), all of which stress the importance of mentoring and role models as well as networking women in order to encourage potential female leaders. Recognizing the viral nature of social media and their potential to foster interactive dialogue, these initial stories will act as seeds for a wider social media campaign that will ask women across the globe to describe their leadership efforts in this domain and will encourage others to actively comment on them. The literature review clearly showed the importance of portraying role models with different characteristics. The social media-based campaign democratizes the process of identifying role models and allows women from different backgrounds to be included. Thus, the stories will feature very high-level, formal leaders as well as women who enact leadership at community levels. In all cases the emphasis is on letting the women speak with their own voices, telling very personal stories rather than presenting official biographies. A specific focus will be placed on women in academia to increase retention of females in higher education programs and in academic and researchrelated jobs. Due to the nature of the social media used for the project, there will even be opportunities for interactive dialogues as the women who are portrayed in the stories can respond to comments made by others.

\section{Implications for the Future of Tourism Education}

The question raised in this paper is how efforts similar to the GWSN initiative could be implemented within the tourism education community. The introduction clearly outlined a need for more female leaders in all areas of tourism. Taking advantage of storytelling and social media, persuasive portraits of female role models could be created to inspire female 
tourism students to become the future generation of academic, government and industry leaders. Following the TEFI spirit of global reach, such stories could be made available on the TEFI website and its social media pages to share role models across geographical boundaries. The success of the initiative would depend on a distributed, social effort of collecting stories at the local level and sharing them with the global tourism community. This would ensure diversity in the stories told and greater access to role models beyond geographic and institutional boundaries. Social media tools provide the technological basis for this to happen.

An important aspect of such an initiative would be to find ways in which such stories could be effectively integrated into existing curricula and courses as well as recruiting efforts for tourism education programs. Given the insights derived from the literature and the case studies, the authenticity of the stories and the ability of tourism students and/or junior tourism academics to identify with them have to be ensured. The education literature suggests that the stories could be used to support autobiographical writing activities that allow students to reflect on their own life experiences and how they relate to the role model stories (Birren \& Deutchmann, 1991). Another question to be addressed is how to measure the effectiveness of such an initiative beyond immediate inspiration by the stories. While reflections by current female leaders on the importance of role models in their own career choices can provide some insights, ultimately longitudinal studies will be needed to measure the long-term effects of exposure to role model stories.

Overall, such an effort would contribute to greater gender-awareness within the TEFI community and beyond and would constitute a concrete follow-up from the discussions in Philadelphia and now Milan. TEFI's new vision statement (To be the leading, forward- 
looking network that inspires, informs and supports tourism educators and students to passionately and courageously transform the world for the better) clearly calls for not only transformational leadership but also transformational learning with the end-goal being transformation of the system that currently discourages women to take on leadership roles. If TEFI played a central role in the collection and distribution of these stories, it could use the initiative to further increase its impact and add another concrete project to its portfolio of already existing initiatives. The key is that it would actively engage a great number of tourism scholars and would foster links with the industry. The project would also direct more attention to the topic of female leadership in tourism, which so far has been largely ignored by tourism educators and researchers. 


\section{REFERENCES}

Ackoff, R. L. (1999). Transformational Leadership. Strategy \& Leadership, 27(1), 20-25. Apostolopoulos, Y., Sönmez, S., \& Timothy, D. J. (Eds.) (2001). Women as producers and consumers of tourism in developing regions. Westport, CT: Praeger Publishers.

Bass, B. M. (1985). Leadership and performance beyond expectations. New York, NY: Free Press.

Beaman, L., Duflo, E., Pande, R., \& Topalova, P. (2012). Female Leadership Raises Aspirations and Educational Attainment for Girls: A Policy Experiment in India. Science, $335,582-586$.

Betz, D. E. \& Sekaquaptewa, D. (2012). My Fair Physicist? Feminine Math and Science Role Models Demotivate Young Girls. Social Psychological and Personality Science, 3(6), 738-746.

Birren, J. E. \& Deutchmann, D. E. (1991). Guiding Autobiography Groups for Older Adults. Baltimore, MD: Johns Hopkins University Press.

Brewer, W. F. (1988). Imagery and text genre. Text, 8, 431-439.

Bruner, J. (2002). Making Stories. New York: Farrar, Strauss, and Giroux.

Byrne Swain, M. (1995). Gender in Tourism. Annals of Tourism Research, 22(2), 247-266.

Cheryan, S., Siy, J. O., Vichayapai, M., Drury, B. J., \& Kim, S. (2011). Do female and male role models who embody STEM stereotypes hinder women's anticipated success in STEM? Social Psychological and Personality Science, 2(6), 656-664.

Costa, C., Carvalho, I., Cacador, S. \& Breda, Z. (2012). Future Higher Education in Tourism Studies and the Labor Market: Gender Perspectives on Expectations and Experiences. Journal of Teaching in Travel \& Tourism, 12(1), 70-90.

Costa, C., Carvalho, I. \& Breda, Z. (2011). Gender inequalities in tourism employment: The Portuguese case. Revista Turismo \& Desenvolvimento, 15, 37-52. 
Dasgupta, N. \& Asgari, S. (2004). Seeing is believing: Exposure to counterstereotypic women leaders and its effect on automatic gender stereotyping. Journal of Experimental Social Psychology, 40, 642-658.

Driscoll, C. \& McKee, M. (2006). Restorying a Culture of Ethical and Spiritual Values: A Role of Leader Storytelling. Journal of Business Ethics, 73, 205-217.

Eagly, A. H. \& Carli, L. L. (2003). The female leadership advantage; An evaluation of the evidence. The Leadership Quarterly, 14, 807-832.

Eagly, A. H. \& Carli, L. L. (2007). Women and the labyrinth of leadership. Harvard Business Review, 85, 62-71.

Earthsummit2002.org (2002). Gender \& Tourism: Women's Employment and Participation in Tourism. Summary of the UNED-UK's Project Report. Accessed online (May 28, 2012) at http://www.earthsummit2002.org/toolkits/women/current/gendertourismrep.html

Ely, R. J. (1994). The Effects of Organizational Demographics and Social Identity on Relationships among Professional Women. Administrative Science Quarterly, 39(2), 203-238.

Ferguson, L. (2009). Analysing the gender dimensions of tourism as a development strategy. Working Paper. Accessed online May 28, 2012 at http://eprints.ucm.es/10237/1/PP_03-09.pdf

Fleming, D. (2001). Narrative leadership: Using the Power of Stories. Strategy \& Leadership, 29(4), 34-36.

Garcea, N., Linley, A., Mazurkiewicz, K., \& Bailey, T. (2012). Future female talent development. Strategic HR Review, 11(4), 199-204. 
Geis, F. L., Boston, M. B. \& Hoffman, N. (1985). Sex of authority role models and achievement by men and women: Leadership performance and recognition. Journal of Personality and Social Psychology, 49(3), 636-653.

Gibson, D. E. \& Cordova, D. I. (1999). Women's and Men's Role Models: The Importance of Exemplars. In A. J. Murrell, F. J. Crosby, \& R. J. Ely (Eds.) Mentoring Dilemmas: Development Relationships within Multicultural Organizations, pp. 115-134. Mahwah, NJ: Lawrence Erlbaum.

Gorman, E. H. (2005). Gender stereotypes, same-gender preferences, and organizational variation in the hiring of women: Evidence from law firms. American Sociological Review, 70(4), 702-728.

Gretzel, U., Fesenmaier, D. R., Lee, Y.-J., and Tussyadiah, I. (2011). Narrating Travel Experiences: The Role of New Media. In R. Sharpley, \& P. Stone (Eds.), Tourist Experiences: Contemporary Perspectives, pp. 171-182. New York: Routledge.

Hjalager, A. (2003). Global Tourism Careers? Opportunities and Dilemmas Facing Higher Education in Tourism. Journal of Hospitality, Leisure, Sport \& Tourism Education, $2(2), 26-38$.

Hoyt, C. L., \& Simon, S. (2011). Female Leaders: Injurious or Inspiring Role Models for Women? Psychology of Women Quarterly, 35(1), 143-157.

Hultin, M. \& Szulkin, R. (2003). Mechanisms of Inequality: Unequal Access to Organizational Power and the Gender Wage Gap. European Sociological Review, 19(2), 143-159.

Isaksen, S. G., \& Tidd, J. (2006). Meeting the Innovation Challenge: Leadership for Transformation and Growth. Chichester, UK: John Wiley \& Sons. 
Kark, R., Waismel-Manor, R., \& Shamir, B. (2012). Does valuing androgyny and femininity lead to a female advantage? The relationship between gender-role, transformational leadership and identification. The Leadership Quarterly, 23, 620-640.

King, B., McKercher, B. \& Waryszak, R. (2003). A comparative study of hospitality and tourism graduates in Australia and Hong Kong. International Journal of Tourism Research, 5, 409-420.

Kinnaird, V. \& Hall, D. (1994). Tourism: A Gender Analysis. Chichester, UK: John Wiley \& Sons.

Kraus, W. (2006). The narrative negotiation of identity and belonging. Narrative Inquiry, 16(1), 103-111.

Lookwood, P. (2006). "Someone like me can be successful": Do college students need samegender role models? Psychology of Women Quarterly, 30, 36-46.

Lockwood, P. \& Kunda, Z. (1997). Superstars and me: Predicting the impact of role models on the self. Journal of Personality and Social Psychology, 73(1), 91-103.

Merriam Webster Online Dictionary (2012). Role model. Accessed online May 28, 2012 at http://mw2.merriam-webster.com/dictionary/role+model.

Merriam Webster Online Dictionary (2012). Social media. Accessed online December 1, 2012 at http://www.merriam-webster.com/dictionary/social\%20media.

Neuhauser, P. C. (1993). Corporate Legends and Love: The Power of Storytelling as a Management Tool. New York: McGraw-Hill.

Packer, R. K., \& Jordan, K. (2001). Multimedia: from Wagner to virtual reality. New York: W. W. Norton.

Padgett, D., \& Allen, D. (1997). Communicating experiences: A narrative approach to creating service brand image. Journal of Advertising, 26(4), 49-62. 
Parkin, M. (2004). Tales for Change: Using Storytelling to Develop People and Organisations. London: Kogan Page.

Pritchard, A., Morgan, N., Ateljevic, I. \& Harris, C. (2007). Tourism, Gender, Embodiment and Experience. In A. Pritchard, N. Morgan, I. Ateljevic, \& C. Harris (Eds.), Tourism and gender: embodiment, sensuality, and experience, pp. 1-12. Cambridge, MA: CABI.

Reuben, E., Rey-Biel, P., Sapienza, P., \& Zingales, L. (2012). The Emergence of Male Leadership in Competitive Environments. Journal of Economic Behavior \& Organization, 83, 111-117.

Rice, C. (2012a). Why women leave academia and why universities should be worried. Accessed online (May 24, 2012) at http://www.guardian.co.uk/higher-educationnetwork/blog/2012/may/24/why-women-leave-academia

Rice, C. (2012b). Why not just any old role model will do: What early career men and women need. Accessed online (May 28, 2012) at http://curtrice.com/2012/01/13/why-not-just-any-old-role-model-will-do-what-early-career$\underline{\text { men-and-women-need/ }}$

Rios, S., Stewart, A. J. \& Winter, D. G. (2010). “Thinking she could be the next President": Why identifying with the curriculum matters. Psychology of Women Quarterly, 34, 328-338.

Rossiter, M. (2002). Narrative and Stories in Adult Teaching and Learning. ERIC Digest no. 241. Accessed online (August 10, 2012) at http://calproonline.org/eric/docs/dig241.pdf

Schank, R. C. \& Abelson, R. P. (1995). Knowledge and memory: The real story. In R. S. Wyer (Ed.), Advances in Social Cognition Vol. 8, pp. 1-85. Hillsdale, NJ: Lawrence Erlbaum. 
Shamir, B., Dayan-Horesh, H. \& Adler, D. (2005). Leading by biography: Towards a lifestory approach to the study of leadership. Leadership, 1(1), 13-29.

Sinclair, M. T. (1997). Issues and theories of gender and work in tourism. In Sinclair, M. T. (Ed.) Gender, Work and Tourism, pp. 1-14. London: Routledge.

Slater, M. D. \& Rouner, D (2002) Entertainment-education and elaboration likelihood: Understanding the processing of narrative persuasion. Communication Theory, 12(2), 173-191.

Stainback, K. \& Kwon, S. (2012). Female Leaders, Organizational Power, and Sex Segregation. The Annals of the American Academy of Political and Social Science, $639,217-235$.

Stake, R. E. (1995). The Art of Case Study Research. Thousand Oaks, CA: Sage.

UN Women (2011). Tourism a Vehicle for Gender Equality and Women's Empowerment. Accessed online (May 28, 2012) at http://www.unwomen.org

UNWTO (2011). Global Report on Women in Tourism 2010. Accessed online (May 28, 2012) at http://unwto.org

Wright, S., Wong, A., \& Newill, C. (1997). The Impact of Role Models on Medical Students. Journal of General Internal Medicine, 12, 53-56.

Zhao, W. \& Ritchie, J.R.B. (2007). An investigation of academic leadership in tourism research: 1985-2004. Tourism Management, 28(2), 476-490. 